\title{
OWNERSHIP RISK IN THE PERSPECTIVE OF ISLAMIC LAW OF CONTRACT: CONCEPT AND APPLICATION ON MODERN PRACTICES
}

\author{
Wan Ahmad Syafiq bin Wan Ahmad Ikram \\ Shariah Compliance Review Unit at Standard Chartered Saadiq \\ Berhad Malaysia \\ email: wan.syafiq@outlook.my
}

\begin{abstract}
Daman Milkiyyah or ownership risk is an important element in Islamic Law of Contract as there are many implications arising from it. This concept also highlights one of the unique features of Islamic Law of Contract which promotes justice in transactions. The lack of a proper understanding of this concept may lead people to breaching Shariah principles as well as dealing with non-Shariah compliant transactions. It is the purpose of this paper to shed light on the fundamental concepts of ownership risk and its application on some of modern financial instruments. This work will write down the scattered though of ownership risk which has been discussed by Islamic classical scholars and continued by matching this concept to the existing modern financial instruments. In the end of the paper, we suggest further enhancement in the financial industry to adhere more towards shariah principle.
\end{abstract}

Keywords: Ownership, risk, liability, damān

\section{INTRODUCTION}

Islam as a religion which brings bless for the universe (rahmatan lil-älaminn) comes to improve the various concepts in life. Of the many things that Islam introduces, one of the points emphasized is to uphold justice. The concept of justice for Islam 
has several dimensions, both for the internal individual and for the mutual good of society. For the social dimension, the concept of Islamic justice can be seen clearly in aspects such as criminal law, family law as well as that one which becomes a lot of spotlight in this modern era: the financial dealing (mu'āmalah māliyah) matters.

In the case of financial dealing, the most distinct character that has been embedded in the teachings of Islam is to bear the risk of all acts as a natural consequence of life. An Islamic scholar is at risk if his fatwa or teachings went wrong. A security guard is at risk if the place he is guarding is burglarized. Also someone who has any property must accept all the consequences and risks, including maintenance costs, risk of damage, and risk of loss.

The last type of risk above is often referred to in the Islamic law of contract as ownership risk. This ownership risk becomes one of the essential cores in the financial dealing model in Islam because justice is really upheld by implementing this concept. This is because it does not make sense when someone else has a car for example but it is us who have to endure the damage done to it. For that, many types of financial dealing that is forbidden at the beginning of the period of Islam because it does not contain the concept of ownership risk.

Since ownership risk is a concept that has long been introduced by Islam, it becomes interesting to discuss it in a modern context. This paper attempts to investigate this by first explaining the concepts. Therefore his paper is divided to two parts, in which the first part will be discussing the general concept of ownership risk in Islamic Law of Contract, while the second part will be discussing on the application of the concept of ownership risk in some of modern financial instruments. 


\section{METHODOLOGY}

Since this study try emphasizes on two thinks which are theoretical and application part, descriptive analysis will suit best for this research. It first tries to find out and elaborate the ownership risk concept through the existing literature considering that it is rare to be found from our classical scholars to discuss this topic specifically. This topic is usually scattered in whole of their fiqh book by relying on some legal maxims (see the work of Shabir, 2007). Next, we will explain in general the existing financial instruments to see how the ownership risk concept is applied there.

\section{DISCUSSION}

\section{Part 1: The Concept of Ownership Risk in Islamic Law of Contract}

The concept of ownership risk is among the fundamental principles which builds the Islamic Law of Contract. There are two Islamic legal maxims which describe this concept as discussed below.

\section{Al-Kharrāj Bi Al-Damān}

The two keywords in the maxim are kharrāj and damān. linguistically, kharrāj means 'yield, return or revenue'. Its meaning in this maxim is the yield or separable benefit or corpus resulting from an owned asset. Linguistically, damān means 'responsibility, liability or guarantee'. Its meaning in this maxim is specifically referring to the liability or an asset in case it is damaged or destroyed (laldin, 2013).

The general meaning of this maxim is that the benefit of an asset is the right of the one (usually the owner) who indemnifies 
it if it is damaged. In other words, a person who is held liable in case an asset is damaged deserves to take its benefit or yield as compensation. Hence, in a sale contract, the buyer, who has the option (khiyar) to return the purchased asset to the seller due to non-disclosure of a defect in it, is entitled to the benefit of that asset during the option period as compensation or his liability to indemnify in case the asset is damaged. Those who do not bear any responsibility are not entitled to any compensation and revenue as the Prophet prohibited the profit earned without bearing liability or risk (Laldin, 2013).

This legal maxim is originated from a few hadiths narrated from the Prophet Peace be Upon Him as described below.

- Narrated from Aishah Radiyallahu 'Anha: A man bought a slave, and he remained with him as long as Allah wished him to remain. He then found defect in him. He brought his dispute with him to the Prophet and he returned him (the slave) to him (the seller). The man said: Messenger of Allah,

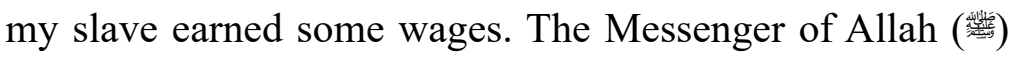
then said: Profit follows responsibility.

- From Abdullah bin 'AmrAbdullah bin 'Amr: "The Messenger of Allah said: 'It is not lawful to lend and sell, nor two conditions in a sale, nor to profit from what is not possessed, nor to sell what one does not have.

From this hadiths above, we know that selling what one does not have means that it is not permissible to gain profit out of something that someone does not bear risk in it. 


\section{Al-Ghurm Bi Al-Ghunm}

This legal maxim is regarded as the inverse version of the previous maxim, in which one who expects profit must accept responsibility in case of loss (Al-Qahtany, 2013). Linguistically, ghurm means 'damage or loss'. Technically, ghurm is defined as: "the burden borne by a person in his wealth in compensation for harm that is neither a crime nor treachery". As for ghunm, linguistically it means 'gain, profit or advantage'. Technically, it means acquiring something which was not owned before.

The general meaning of the maxim is that the owner of an asset has to bear all the risks and costs that attend ownership of the asset since he is entitled to enjoy any benefit resulting from it just as non-owners have no right to share in the benefits of ownership, so too, no one but the owner should have to bear the attendant risks and costs (Laldin, 2013).

From here, we can make correlation between riba (usury), sale (al-bay') and risks (ghurm). Allah said in the Quran that: "Allah has permitted trade and forbid riba" (Al-Baqarah: 275). From the understanding of this verse, Allah has encouraged us to avoid riba which bear no risk and to go for al-bay' which is not risk-free. Risk-taking and risk sharing are a manifestation of Islamic ethical principles, such as just and cooperation. Al-bay' is therefore legitimate because it assumes risk-taking while profit from loans (i.e. riba) rejected the idea of risk sharing and risktaking. Al-bay' is a contract of sale, and no sale in Islam is free from risks. Profit from sale is an outcome of risk-taking, as the seller takes the risk to make sure that the market for the goods 
exist, that the price is right and goods are in good condition. He will lose money if the goods are destroyed by natural calamities or if the market price dropped below cost. This is a legitimate way of making profit. This type of risk is called ghurm. In economics, ghurm means price and market risks. In finance, it means systematic risks (Rosly, 2010).

Apart from the legal maxim, it is necessary to mention in discussing the concept of ownership risk in Islam that that when someone is holding someone else's property, regardless of whether it is done via contracting means or without it, he is either holding the asset in the capacity of a trustee (yad amānah) or a liable party (yad damān). Further elaboration on these two types of position is in the following notes.

\section{Yad Amānah}

In principle, someone is said to have a trustee position of a property (yad amānah) if the holding of the property is done via permissible means in Shariah or with the permission from its owner or someone who has authority over it, but without the intention from the holder to own the property as his ownership. For instance, a lessee in Ijarah contract, a custodian in Wadiah contract, a partner in Musyarakah contract and a mudharib in Mudharabah contract, all of them are holding the property given to them in the capacity of a trustee (yad amānah). This is because, the possession of the property on them is not meant to transfer its ownership, but rather for them to hold it for a certain period of time to achieve certain objective from the use of the respective contracts. Muslim scholars have unanimously agreed that, a trustee of a property is not liable in case of damage or destruction of the property unless there is transgression or negligence from him. 


\section{Yad Damān}

Yad damān can be defined as a state where a person takes possession of a property or a form of wealth as an owner or to the possessor's benefit, but not as a trustee (ameen). Examples of dealings based on yad damān include taking possession by a buyer, borrowing, pawning or rahn (the party holding the pawned items), usurpation (holding by a usurper), etc. Also included in the category of yad damān is someone who is originally holding yad amanah position, but due to transgression or negligence, his position is now changed to yad damān. The Shariah ruling on yad damān maintains that whoever lays his hand on a form of wealth by way of possession or use is bound to guarantee it in all circumstances, whether the object possessed perishes because of some natural catastrophe or act of God (force majeure), or when the possessor simply fails to return it to its rightful owner. A possessor is also bound to guarantee in the cases of intentional or unintentional destruction. The discussion on ownership risk is closely related to the yad damān position.

It is also interesting to see whether transferring ownership risk from the original owner (yad damān holder) to person who holds yad amanāh as in the case of mudarabah, musharakah and ijarah contracts. Muslim scholars has two opinion regarding this matter. (Abu Zaid, 1996)

The first opinion says that the clause is invalid. This opinion is held by the majority of Muslim scholars from Hanafi, Maliki, Shafii and Hanbali school. This opinion is based upon a few hadiths where one of which is the hadith of Aishah and Barirah. Barirah the slave came to Aishah to seek her help for her manumission. However, Barirah's masters agreed to free her on a condition that the wala' was to remain with him. Aishah brought this issue to 
the Prophet and the Prophet said: "Buy Barirah and manumit her and the wala' (right of freeing person from slave state) will be

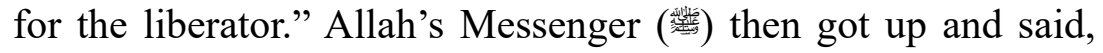
"What about those people who stipulate conditions that are not present in Allah's Laws? If anybody stipulates a condition which is not in Allah's Laws, then what he stipulates is invalid. Allah's Condition (Laws) are the truth and are more solid" (see the hadith of Bukhari no. 2560).

From this hadith, we can learn few lessons relating to the ownership risks. Firstly, in this hadith, the Prophet has clearly stated that, any condition which is not recognized in Allah's laws is not valid. Therefore, any condition to transfer ownership risk from the original risk owner to others is not valid as it is not supported by any Quranic verses as well as the hadiths of the Prophet.

Secondly, we can understand from the hadith that the prohibition of stipulating wala' on other than the liberator of the slaves contains an element of changing the inherent nature and implication of the contract. Shariah law has made the various Shariah contracts to have unique characteristics with certain rulings and implications. The condition to transfer the ownership risk to other than the original owner contains an element of changing the inherent nature of the contract resulting to a different implication to the contracting parties which is not intended to from Shariah perspective. In addition, this kind of arrangement may lead to the violation of the objective of Shariah. Therefore, the inclination is to invalidate this kind of arrangement by using analogy to the above hadith.

Thirdly, the arrangement to transfer ownership risk to other than its original risk owner contains high possibility of falling into 
prohibited transactions in Shariah, especially for contracts which are used for investment purposes and for gaining profit such as exchange and partnership contracts. For instance, the prohibited transactions that this arrangement may be leading to are such as, to gain profit out of something that one does not bear the risk, and also the involvement with riba. To illustrate, in mudharabah contract, if the return is to be guaranteed by the mudārib (despite the mudārib is yad amanāh holder), this arrangement has altered the nature of the mudharabah contract to resemble a Qard, in which the contract now needs to follow the qard's strict requirement such as no interest is to be charged on the principal amount.

The second opinion says the clause is valid. This opinion is held upon by some of Hanafi scholars specifically for borrowing contract (al-'äriyah), and also by some of Maliki scholars and some contemporary scholars. Their arguments are based on a few hadiths as below.

- It is narrated by Safwan Bin Umayyah that, the Prophet had borrowed from him a breastplate during the Hunain war on the basis of yad dhaman despite the original ruling of al'âriyah (borrowing) is a amanah.

Based on this hadith, this group of scholars has justified the permissibility of transferring the ownership risk of a contract to others. However, this hadith is regarded as a weak hadith which cannot be used in deciding a ruling.

- The second hadith that they rely on is the Prophet's saying that: "Muslims will be held to their conditions."

According to this group of scholars, the condition to transfer risk is valid because it can be included in this general principle as well. However, we can argue against this opinion by saying that 
this general principle is actually confined to only conditions that are present in the Allah's law. This is based on the following part of the abovementioned hadith which says: "any conditions which are not present in Allah's books is not valid."

Based on the above arguments by the two groups of scholars, the inclination is to the opinion that says the impermissibility to transfer risk to other parties due to stronger arguments than those who opined otherwise.

\section{Part 2: The Application of the Concept of Ownership Risk in Some of Modern Financial Instruments from Islamic Law of Contract's Perspective}

\section{Preferred Stock}

According to Finance literatures, preferred stock is referring to the type of stocks which has preference over common stock in the payment of dividend and in the distribution of corporation assets in the event of liquidation. Preference means that the holders of the preferred shares must receive a dividend (in the case of an ongoing firm) before holders of common shares are entitled to anything.

Some features of preferred stock include (Ross et al., 2008).

Senior securities - the seniority of preferred stocks applies to both the distribution of corporate earnings (as dividends) and liquidation of proceeds in case of bankruptcy. With preferred, the investors are standing closer to the front of the line for payment than common shareholders, although not by much.

Payment of dividends - preferred stockholders are prioritized in receiving payment of dividend from the company. Common stock dividends are paid after the company's obligations to all preferred stockholders have been satisfied. Dividends payable on 
preferred stock are either cumulative or noncumulative; most are cumulative. If preferred dividends are cumulative and are not paid in a particular year, they will be carried forward as an arrearage. Usually, both the accumulated (past) preferred dividends and the current preferred dividends must be paid before the common stockholders can receive anything. This kind of feature of preferred stock guarantees a return to the stockholders despite the company making profit or not. In addition, the dividends paid on preferred stock are normally higher than common stock.

Capital guaranteed - in certain cases of preferred stock, the company may guarantee the return of original capital to the preferred stockholder during liquidation, even when the company is losing. This way, the interest of the preferred stockholder is always protected and regardless the performance of the company.

For the purpose of this discussion, we would like to highlight two Shariah issues concerning the ownership risk in the application of preferred stock in Capital Market.

First issue: the preferred stockholders are given the priority over other stockholders in receiving back their original capital in full during liquidation of the corporation (Sharikah).

Among the basic principles of a Musharakah contract which the modern corporation is based upon is that, all partners shall bear the risk of the business proportionately to their capital contribution, and no one of the partners shall be made responsible to the risk beyond the actual contribution he has made into the partnership. By having the ownership risk of the business under their responsibility, the Shariah has made all the partners to be eligible in receiving return generated from the business partnership (Al-Haqil, 2011). This feature of Musharakah is aligned with the two Islamic legal maxims discussed earlier. However, the features 
of a preferred stock are shifting the ownership risk of particular partners to be borne only by common stockholders which makes the capital of the preferred stockholders is guaranteed from any loss. This practice is contrary to the abovementioned principle of Musharakah which encourages risk sharing among the partners. By having the capital guaranteed, the preferred stockholders are gaining profit without bearing the ownership risk in the partnership which the practice has been prohibited by the Prophet in his saying: "It is not permissible to lend on the condition of a sale, or to stipulate two conditions in one transaction, or to make a profit on that which you do not bear the risk" (see the hadith narrated by Nasai no. 4630).

Second issue: the feature of a preferred stock has given its holders the priority over other stockholders in receiving dividend payments, which usually a certain portion of the profit will be segregated specifically for them, and only after the profit is distributed to them, the remaining will be distributed to other stockholders. This kind of arrangement has made it possible for the preferred stockholders receiving profit distribution above the proportion of actual capital contribution they have made. This additional profit they received is considered as the profit on which the preferred stockholders do not bear the risk. As mentioned above, each partner in the Musharakah contract bears the risk proportionately to their capital contribution. And the profit they received from this partnership shall also be proportionate to the size of their contribution. If in any way the partner received a profit above the proportion of their capital contribution, it must be compensated either by certain work contributed to the business (the additional profit will be considered as a fee for him), or to bear additional risk. Otherwise, the additional profit is considered 
as an illegitimate profit. Resolution of International Islamic Fiqh Academy pertaining to preferred stock:

"It is not permissible to issue preferred stock, because it contains financial benefits (to the preferred stockholder) that will lead to the guarantee of capital or to guarantee a certain amount of profit or to give priority (in receiving back the capital) during liquidation or during profit distribution. However, it is permissible to give certain features to some stocks relating to the procedural and administrative aspects."

\section{Wadi'ah-based Deposit Products in Islamic banks in Malaysia}

In Wadi'ah-based deposit products, a bank is deemed as a keeper and trustee of funds. A person deposits funds in the bank and the bank guarantees refund of the entire amount of the deposit, or any part of the outstanding amount, when the depositor demands it. The depositor, at the bank's discretion, may be rewarded with a hibah (gift). This kind of deposit arrangement is termed as Wadi'ah yad damānah which resembles a Qard (lending) contract in the context of Malaysia.

According to the Shari'ah Standard on Qard contract which was published by Bank Negara Malaysia, a Qard contract is established when ownership of a sum of money belonging to the lender is transferred to the borrower and the borrower is obliged to repay the lender in full. From this definition, it is safe to say that in Wadi'ah-based deposit, when a customer of a bank deposits a sum of money, he actually transfers the ownership of that money to the bank so that the bank can utilize it for its own purpose, with the obligation on the bank to repay it whenever the customer needs it. 
Based on the two legal maxims discussed above, the benefit of an asset can be enjoyed only if one bears its ownership risk. Meaning that, the loss of the asset will be borne by him in the event of force majeure or natural calamity. In the case of Wadiahbased deposit product, a depositor transfers the ownership of the money to the bank and the bank is liable to repay the depositor. This transfer of ownership from depositor to the bank has made the bank to bear all the risk associated with that money. Because of this risk-bearing, any return generated from the utilization of that money is solely owned by the bank. Customer does not have any claim over and above the principal amount deposited as he does not bear the risk of that money in the first place. Any promise or guarantee to return the money to the depositor with excess will be tantamount to riba. Any return above the principal amount must be justified by a valid reason approved by Shariah such as in a Mudharabah contract where the customer bears the ownership risk.

In the current practice of Wadiah-based deposit by Islamic banks in Malaysia, banks are normally repaying the deposited money to their customer with some excess so that it can gain competitiveness against other banks. This excess is termed as "discretionary hibah". In principle, since the bank owns the profit generated from the lended money, it is up to the bank to spend the profit the way it wants. And this hibah is totally at the discretionary of the bank whether or not to give it, or on what amount to pay it. If we look at this kind of arrangement superficially, it has some kind of resemblance to the conventional deposit product which guarantees a certain rate of return on the deposited money. However, the Shariah requirement for a Wadiah-based deposit is that, the discretionary hibah rate which the bank may pay to their 
customer cannot be publicly disclosed upfront as it may lead to a wrong perception of the bank guarantees a certain rate of return on the deposits.

Musyarakah Mutanaqisah-based (Diminishing Partnership) Property financing offered by Islamic banks in Malaysia

For the discussion on this type of product, we will use a sample structure of property financing product offered by one of Islamic banks in Malaysia. The applicable Shariah principles for Diminishing Musharakah products offered by the bank consist of Musharakah and Ijarah.

The Musharakah and Ijarah contract are often bundled all together to resemble new product called Diminishing Musharakah. It is descrbed as the transaction whereby customer and the bank jointly acquire and co-own an asset/property. For instance, customer forms partnership with the bank to acquire a property, whereby customer owns 10 percent of the property and the other 90 percent is owned by the bank. Since it is the customer who wants to own the complete ownership of the property, the bank will sell and lease its 90 percent share in the property to the customer under ijarah (lease) contract for 30 years. Customer will pay monthly installment to the bank in which one portion of it will be used to acquire bank's equity and the other portion will be used as rental payment to the bank. Through this monthly installment, the bank's ownership in the property will gradually decline while customer's ownership increases. The ownership of the property will progressively move towards the customer and the financing ends when the customer owns 100 percent ownership of the property.

In assessing the Shariah aspects of this financing facility, we have reviewed the Terms and Conditions document of the facility 
offered by the bank, and based on our review, we would like to highlight the issue of Takaful coverage of the financed property which will be borne solely by the customer, while in fact the property is jointly owned by the bank and the customer, with the bank as the majority owner of the property at the initial phase of the financing tenure. Below is the quoted clause from the Terms and Conditions document of the facility:

"In consideration of the Bank giving and/or agreeing to give to the Customer the exclusive right to occupy, possess, use and enjoy the Property, the Customer must obtain and maintain takaful coverage of not less than the outstanding Buyout Amount or for such amount as may be acceptable to the Bank on the Property against all insurable risks including but not limited to, loss or damage by fire, explosion, lightning, tempest, flood, riot, civil commotion, strike and malicious acts and other risks as the Bank may require. The Customer must, if permitted, name the Bank as an additional party covered in the takaful policy and its renewals or if not permitted, to include the Bank as financier and/or loss payee."

According to the legal maxim "al-ghurm bi al-ghunm", the person who enjoys the benefit of an asset shall be the one who bears the cost to sustain the asset. In our case here, the Takaful coverage is subscribed in order to protect the property in the event of loss, without which the loss shall be borne jointly by the owner of the property, which is the bank and the customer as both of them bear the ownership risk in that asset. In other words, the Takaful is subscribed in order to protect their interest as the joint 
owner of that property. Hence, the arrangement for the customer to be the sole bearer of the Takaful cost seems inappropriate to me as the benefit of the Takaful coverage is actually for the interest of both the bank as the majority owner and the customer as the minority owner. Both the bank and the customer should jointly pay for the Takaful cost as it is for the benefit of the two of them. In my point of view, this kind of arrangement seems to breach the principle of "al-ghurm bi al-ghunm" which says, the person who enjoys the benefit of an asset shall bear its liability.

\section{Sukuk Musharakah}

In definition, Sukuk Musharakah is a type of financing instrument whereby investors (Sukuk holders) form a Musharakah partnership as partners with the issuer for the purpose of undertaking a venture to invest directly in an identified asset or business. Each Sukuk Musharakah shall represent the respective Sukuk holder's undivided proportionate interest in the Musharakah Venture. Proceeds raised from the Sukuk Musharakah shall be the capital contribution of the Sukukholders to the Musharakah Venture. Income from the Musharakah venture shall be distributed to each partner based on a profit sharing ratio which will be determined prior to the issuance of the Sukuk Musharakah. Any losses incurred in the Musharakah Venture shall be borne by each Partner in proportion to each partner's respective capital contribution in the Musharakah venture. The sukuk issuer shall also grant to the Sukukholders a purchase undertaking whereby the issuer shall undertake to purchase the sukukholders' interest in the Musharakah venture at the exercise price on the maturity date. 
For the shariah issue part, we find there is an undertaking from the Sukuk issuer to top up the profit amount distributed to the investors in the event there is a shortfall between the expected profit rate of the sukuk and the actual realized profit, making the true risk bearing of a Musharakah on the part of Sukuk holders is not reflected.

Below is the said clause quoted from the Terms \& Conditions of a Sukuk Musharakah issued by Northport (Malaysia) Berhad:

"Any shortfall between the Periodic Distribution Amount and the Sukukholders' entitlement to distributable income generated from the Musharakah Venture shall be paid by Northport as a top up payment. The top up payment will be set-off against the Exercise Price payable by the Obligor following the exercise of a purchase undertaking. "

In principle, all partners in a Musharakah partnership own the underlying asset of the business proportionately to their capital contribution. As such, the ownership risk of the Musharakah that they have to bear must be also proportionate to this portion, and no partner shall be responsible for the risk more than what they have contributed. As for the profit distribution, it does not necessarily to be proportionate to the capital contribution, but inactive partners who do not involve in managing the business shall not be entitled to the profit more than their portion of capital contribution. And as generally known, Sukuk holders do not involve directly in managing the business (Dusuki, 2010).

Thus, from the aforementioned clause, by guaranteeing the profit distribution to be always fixed regardless of the performance of the underlying business, I see this does not reflect the true 
bearing of ownership risk on the part of Sukuk holders as the ownership risk bearer supposedly to be exposed to the market risk which may affect the performance of the underlying business of the Sukuk Musharakah. The Sukuk holders are entitled to profit because of ownership risk they have in the business. Similarly, they must also be entitled to suffer loss arising from his ownership risk (Usmani, 2007). The profit distribution to the Sukuk holders should rely totally on the performance of the business. On my opinion, the abovementioned clause has violated the principle of Musharakah in the aspect of the sukuk issuer is guaranteeing the profit distribution to the Sukuk holders which contrary to the ownership risk principle.

Purchase undertaking by the Sukuk Issuer: The price of which the issuer will repurchase the asset is predetermined which include the original amount of Musharakah capital plus accrued profit. On my opinion, this is inappropriate way to determine the repurchase price of the asset. The price should be determined by its market value, or by a price to be agreed during the actual purchase date by taking into consideration all the economic aspects which may affect the real value of the asset at maturity date.

The question is what if the market price of the asset is actually depreciated below its nominal price? It is easy to think that this actually benefits the issuer as they can buy the asset with lower price. Anybody with a sane mind would have definitely buy an asset with a lower price. However, this is not the case in this structure of sukuk Musharakah. It is structured in a way that the capital of the investors is fully protected, which resembles a lot like the conventional bond and has the same economic outcome. In my view, this kind of structure does not reflect the risk bearing on the part of investors which contrary to the principle 
of Musharakah. The true ownership risk bearing should entitle the Sukuk holders to be exposed to the market risk of the asset which may affect its value in the future. To illustrate, if the market price of the asset is above the Musharakah capital, Sukuk holders may gain higher profit from it. Similarly, if the market price of the asset is lower than the original Musharakah capital, the Sukuk holders shall be entitled to suffer loss arising from his ownership risk in the asset. From here, a question arises as to whether the investors are actually eligible to receive the profit while the true risk bearing is not reflected in this sukuk structure? Again, it is contrary to the fundamentals of muamalat in Islam, namely alghurm bi al-ghunm and al-kharrāj bi al-damān.

\section{CONCLUSION}

The above discussion on the concept of ownership risk and its application in the modern financial system shall have shed some lights for the readers to understand this important element in Islamic Law of Contract. The importance of this concept lies in the fact that it determines the eligibility of a person to gain profit from a transaction, as well as the implications it has on a person in terms of right and obligation arising from the ownership risk. From some of the applications brought into this paper, we noted more enhancement need to be done to the practice of Islamic Finance industry to ensure full compliance with Shariah, as well as to achieve the objectives of Shariah from the Islamic Law of Contract. This should be a continuous effort by all the stakeholders for the prosperity of the society by complying with Shariah in commercial transactions. 


\section{DISCLAIMER}

This paper represents author's personal opinion. None of the written thought above shall be interpreted as reflecting neither any companies nor affiliations attached to the author.

\section{REFERENCE}

\section{Arabic}

أبو زيد، محمد عبد المنعم، 9999 ـ ـ الضمان في الفقه الإسلامي وتطبيقاته في

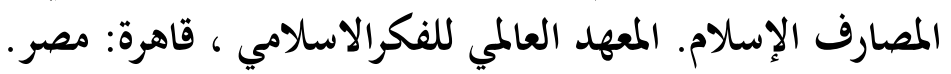
الحقيل، ابن عبد الله ابن محمد، ج ب ـ 1 ا ـ ربح ما لم يضمن )دراسة تأصيلية تطبيقية). دار الميمان للنشر والتوزيع. رياض: المئ المملكة السعودية. شبير، محمد عثمان، Y . . . . . القواعد الكلية والضوابط الفقهية في الشريعة الاسلامية.دار النفآس، بيروت: لبنان.

القحطائ، فواز محمد علي فارع، ج • ا ب. القواعد والضوابط الفقهية المؤثرة في المعاملات المالية الاسلامية. مؤسسة الرسالة الناشرون. بيروت: البرات لبنان

\section{English}

Brealey, R.A., Myers, S.C. and Marcus, A.J., 2007. Fundamentals of Corporate Finance. McGraw-Hill.

Dusuki, A.W., 2010. Do equity-based Sukuk structures in Islamic capital markets manifest the objectives of Shariah? Journal of Financial Services Marketing, 15(3), pp.203-214.

Laldin, M.A., 2013. Islamic legal maxims \& their application in Islamic finance. International Shari'ah Research Academy for Islamic Finance.

Rosly, S.A., 2005. Critical issues on Islamic banking and 
Journal of Islamic Economic Laws-July, Vol. 1, No. 1, 2018

financial markets: Islamic economics, banking and finance, investments, Takaful and Financial Planning. Dinamas Publishing

Usmani, M.T., 2007. Sukuk and their contemporary applications. Translated from the original Arabic by Sheikh Yusuf Talal DeLorenzo, AAOIFI Shari'a Council meeting, Saudi Arabia. 